CZASOPISMO INŻYNIERII LA¿OWEJ, ŚRODOWISKA I ARCHITEKTURY JOURNAL OF CIVIL ENGINEERING, ENVIRONMENT AND ARCHITECTURE JCEEA, t. XXXIII, z. 63 (2/I/16), kwiecień-czerwiec 2016, s. 65-74

\author{
Galina KALDA ${ }^{1}$ \\ Izabela MIETUS ${ }^{2}$
}

\title{
OCHRONA ŚRODOWISKA W TURYSTYCE NA PODKARPACIU
}

\begin{abstract}
W artykule prezentowano analizę środowiska województwa podkarpackiego zanieczyszczanego odpadami turystycznymi. Województwo podkarpackie jest popularne z miejsc aktywności turystycznej oraz dobrej sieci infrastruktury turystycznej. Jak pokazują badania, Podkarpacie jest województwem z nieznacznym zanieczyszczeniem środowiska. Wody powierzchniowe są głównym źródłem zapotrzebowania na Podkarpaciu. Poprzez swoje położenie geograficzne województwo można uznać za jedno z niewielu miejsc z Polsce, gdzie sezon turystyczny trwa praktycznie cały rok. Podkarpacie przez to przyciąga turystów, którzy pragną aktywnego odpoczynku przez obcowanie z przyrodą. Nagły rozwój turystyki został spowodowany promowaniem województwa jako regionu atrakcyjnego turystycznie i przychylnego turystom. Jednym z większych problemów hamujący rozwój turystyki jest zbyt mała sieć informacji turystycznej. Rozmieszczone są one w mało strategicznych dla turystów miejscach. Znaleźć je można nawet kilka kilometrów od przystanków autobusowych czy dworcach kolejowych. Dla turystów, którzy przyjeżdżają do nowego miejsca, ważne jest uzyskanie jakichkolwiek informacji o mieście, noclegach czy zabytkach, które znajdują się w okolicy. Analiza pokazała, że turyści wytwarzają średnio do 30 razy więcej odpadów, niż przeciętny mieszkaniec województwa podkarpackiego, co spowodowane jest wykorzystywaniem większej ilości opakowań jednorazowych, wytwarzaniem odpadów, takich jak resztki żywności, tekstylia, szkło itp. Po przeprowadzonej analizie stwierdzono, ze turystyka pośrednio wpływa na zanieczyszczenia gleby, powierza oraz ma nieznaczny udział w poziomie hałasu komunikacyjnego. Nie oznacza to jednak, że jej wpływ jest niegroźny i nieistotny. Aby o tym się przekonać należy wykonać specjalne badania, które określiłyby stopień, w jakim turystyka może przyczynia się do tego typu zanieczyszczeń.
\end{abstract}

Słowa kluczowe: Podkarpacie, turystyka, zanieczyszczenie, środowisko, sieć turystyczna

\footnotetext{
${ }^{1}$ Autor do korespondencji/corresponding author: Galina Kalda, Politechnika Rzeszowska, al. Powstańców Warszawy 6, 35-959 Rzeszów, tel. +48 17 8651068, kaldagal@ prz.edu.pl

2 Izabela Miętus, Politechnika Rzeszowska
} 


\section{Wprowadzenie}

Ochrona środowiska w turystyce jest ważna, ponieważ coraz bardziej ingeruje w środowisko przyrodnicze. W województwie podkarpackim nie dotyczy to jednego regionu a praktycznie całego województwa, dlatego to wymaga szczegółowej analizy rozwoju turystyki na przestrzeni kilku lat.

Turystyka jest coraz bardziej popularną formą wypoczynku, nabierania sił fizycznych i psychicznych, aktywności fizycznej połączonej z poznawaniem nowych miejsc, kultury i społeczności. Łączy ona ze sobą aspekty wielu dziedzin. Rozwój turystyki jest w województwie podkarpackim ważny pod względem gospodarki i napędu rynku pracy, ponieważ wiele przedsiębiorstw utrzymuje się z takich właśnie form działalności. Województwo podkarpackie jest popularne z miejsc aktywności turystycznej oraz dobrej sieci infrastruktury turystycznej. Ze względu na różnorodność klimatu i rzeźby terenu formy uprawiania turystyki są urozmaicone. Również ochrona środowiska czerpie korzyści z rozwoju turystyki, przez co należy o nią dbać i rozwijać.

Podkarpacie jest województwem z nieznacznym zanieczyszczeniem środowiska. Ochrona środowiska nastawiona jest na zabezpieczenie najważniejszych walorów i form przyrody poprzez tworzenie na terenach wartościowych przyrodniczo parków narodowych, rezerwatów przyrody i parków krajobrazowych. Formy przyrody dostępne do zwiedzania turystom zabezpiecza się tak aby ingerencja turystów i obecność ich na cennych terenach nie narażała środowiska na dewastację. W fazie tworzenia są plany ochrony oraz systemy monitorowania oddziaływania na środowisko przyrodnicze turystów i działalności gospodarczej powiązanej z turystyką. Plany i strategie Podkarpackie jakie uzgadnia się chroniąc środowisko uwzględniają zasadę zrównoważonego rozwoju.

\section{Walory turystyczne województwa podkarpackiego}

\subsection{Podział województwa ze względu na poziom rozwoju turystyki}

Poprzez swoje położenie geograficzne województwo można uznać za jedno $\mathrm{z}$ niewielu miejsc z Polsce, gdzie sezon turystyczny trwa praktycznie cały rok. Podkarpacie przez to przyciąga turystów, którzy pragną aktywnego odpoczynku przez obcowanie z przyrodą. W lecie poprzez piesze wędrówki, jazdę konną lub turystykę rowerową, w zimie zawsze można liczyć na sprzyjające warunki do uprawiania sportów zimowych. Zimowymi stolicami turystycznymi na Podkarpaciu stają się Ustrzyki Dolne, Lesko, Przemyśl i Puławy ponieważ tam znajdują się wyciągi narciarskie z ośrodkami sportowymi. Dzięki utworzeniu narciarskiego szlaku turystycznego można podziwiać góry na nartach. W województwie organizowane są rajdy terenowe zrzeszające tysiące pasjonatów motoryzacji. Dostępne są obiekty i miejsca, gdzie można uprawiać sporty wyczynowe takie jak skoki spadochronowe (lotnisko w Krośnie i lotnisko Jasionka koło Rzeszowa). 
Województwo Podkarpackie jest bardzo zróżnicowane jeżeli chodzi o natężenie turystyki w poszczególnych miejscach. Ruch turystyczny nie jest jednorodny, przez co można podzielić go na trzy strefy. Na ten podział w dużej mierze mają wpływ walory i oferty turystyczne. Rys. 1 przedstawia przykładowy podział województwa Podkarpackiego na trzy obszary turystyczne uwzględniające nasilenie ruchu turystycznego w poszczególnych powiatach. Sporządzony on został z danych podanych w ,Strategii Rozwoju Podkarpacia na lata 20072020". Największe nasilenie ruchu turystycznego jest w I obszarze, mniejsze w II, natomiast najmniejsze w III.

I obszar - najbardziej wysunięty na południe. Ze względu na rozwój turystyki górskiej w Bieszczadach i Beskidzie Niskim najwięcej schronisk turystycznych jest w tychże powiatach. Tereny te odwiedzane są ze względu na podziwianie różnych form przyrody, bliskość gór, jezior, dostępność sanatoriów. Turystyka rozwija się również na obszarach wiejskich, skutkiem czego powstaje wiele gospodarstw agroturystycznych.

II obszar - centralny. Miasta na tym obszarze oferują turystom bazę hotelową wraz z ośrodkami wypoczynkowymi. Największy odsetek odwiedzających te tereny - to osoby podróżujące i zatrzymujące się w nich w sprawach, np. służbowych. Powstają tu liczne restauracje i biura podróży. Wyższe są też kwalifikacje obsługi klienta $\mathrm{z}$ racji częstych odwiedzin turystów zagranicznych. Bardzo duże znaczenie na tym obszarze ma lotnisko w Jasionce $\mathrm{k}$. Rzeszowa oraz mniejsze lokalne w Mielcu i Krośnie - to dodatkowo poprawia komunikację międzymiastową oraz międzynarodową.

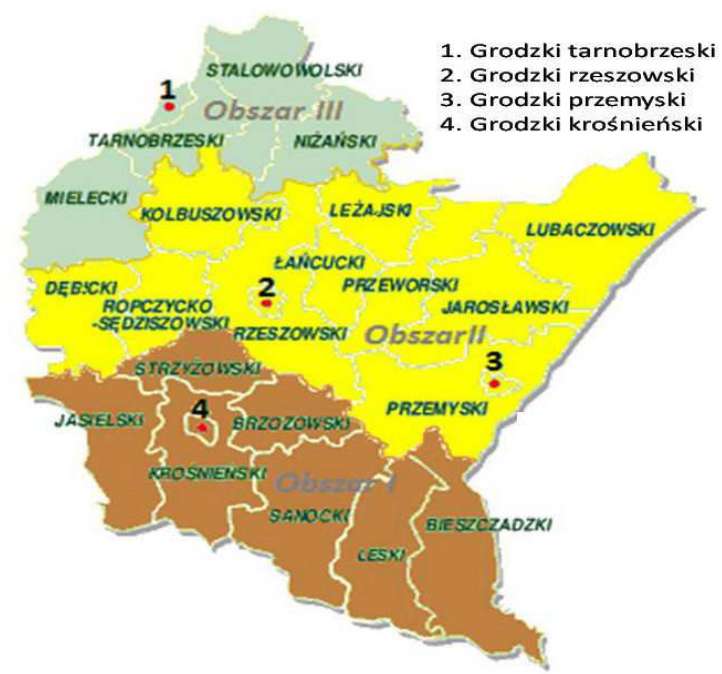

Rys. 1. Podział województwa podkarpackiego na charakterystyczne obszary turystyczne na podstawie [4]

Fig. 1. Division Podkarpackie typical tourist areas on the basis of [4] 
III obszar - północny. Występuje tu niewiele walorów przyrodniczych a co za tym idzie najmniejszy ruch turystyczny. Jego główna lokalizacja - to pasmo Roztocza i Wyżyny Lubelskiej. Przeważa tu turystyka piesza i kulturowa. Baza noclegowa jest niewielka, nastawiona w szczególności na turystów indywidualnych [1].

\subsection{Rozwój turystyki na Podkarpaciu}

Walory przyrodnicze są głównym czynnikiem przyciągającym turystów. Dostępność cennych przyrodniczo miejsc powoduje wzrost zapotrzebowania na usługi turystyczne. Zbyt duża liczba turystów może powodować degradację środowiska naturalnego. Zagrożenia, które wynikają z nasilającego się w ostatnich czasach ruchu turystycznego to m.in. zbyt duża koncentracja turystów na danej przestrzeni (rozbudowa infrastruktury turystycznej na wyznaczonym obszarze), budowa masowych baz turystycznych na obszarach atrakcyjnych przyrodniczo (domki letniskowe), niewystarczająca ilość oznakowań na szlakach, zbyt mała sieć komunikacyjna (powodująca duże natężenie w ruchu samochodowym na głównych drogach), mała świadomość turystów i przedsiębiorców w sferze ekologicznego postępowania i dbania o środowisko naturalne [2].

Nagły rozwój turystyki został spowodowany promowaniem województwa jako regionu atrakcyjnego turystycznie i przychylnego turystom. Podkarpacie objęto projektem, który zaczęto realizować we wrześniu 2010 r. pt."Poszerzając Horyzonty - transgeniczna promocja turystyki Podkarpacia i Kraju Rzeszowskiego". Miał on na celu poszerzenie wiedzy o atrakcyjności województwa podkarpackiego nie tylko polskich turystów ale i zagranicznych.

Jednym z większych problemów hamujący rozwój turystyki jest zbyt mała sieć informacji turystycznej. Rozmieszczone są one w mało strategicznych dla turystów miejscach. Znaleźć je można nawet kilka kilometrów od przystanków autobusowych czy dworcach kolejowych. Dla turystów, którzy przyjeżdżają do nowego miejsca, ważne jest uzyskanie jakichkolwiek informacji o mieście, noclegach czy zabytkach, które znajdują się w okolicy. Nie tylko lokalizacja punktów informacji jest barierą dla turystów, również znajomość języków obcych, którzy udzielają informacji jest na niezadowalającym poziomie. Znajomość komunikacyjnego języka obcego dla zagranicznych gości jest bardzo przydatna a nie wszystkie niezbędne informacje można znaleźć w przewodnikach. Urozmaicenie spędzanego czasu w województwie podkarpackim można zwiększyć przez kierowanie ofert turystycznych do określonych grup wiekowych. W województwie podkarpackim brakuje ośrodków, które nastawione są jedynie na usługi oferowane do osób w podeszłym wieku, którzy pragną odpocząć od zgiełku miast, a nie koniecznie pragną przebywać w sanatoriach. Rozwój turystyki, która zachęcałaby seniorów do wyjazdów i zwiedzania nie tylko Podkarpacia poszerzałaby ilość odbiorców oraz wygenerowałaby dodatkowe źródła dochodu. Ważną rolę w regulowaniu i kontrolowaniu rozwoju ruchu turystycznego ma regulacja przez organy administracyjne aktów prawnych normujących zasady. 


\section{Zanieczyszczenia środowiska Podkarpacia związane z turystyką}

System gospodarowania odpadami komunalnymi jaki funkcjonuje w województwie podkarpackim opiera się na ustawie „O utrzymaniu czystości i porządku w gminach". Za zbieranie oraz właściwe zagospodarowanie odpadów odpowiada samorząd terytorialny [3]. Tabela 1 przedstawia ilość zebranych odpadów w ciągu roku w przeliczeniu na ilość mieszkańców województwa w 2014 r. z uwzględnieniem turystów, przebywających w tym roku (761 500 os.). Średnia długość pobytu turystów w województwie - to ok. 4 dni. Przyjęto, że mieszkańcy byli obecni przez 339 dni na terenie województwa. W poprzednich latach wytworzonych odpadów mogło być więcej niż pokazują statystyki. Przedstawione dane wykazują, że turyści wytwarzają średnio do 30 razy więcej odpadów, niż przeciętny mieszkaniec województwa podkarpackiego, co spowodowane jest wykorzystywaniem większej ilości opakowań jednorazowych, wytwarzaniem odpadów, takich jak resztki żywności, tekstylia, szkło itp.

Tabela 1. Ilość odpadów zgromadzonych w 2012 r. uwzględniającą ilość turystów i mieszkańców na podstawie [4]

Table 1. The amount of waste collected in 2012. Taking into account the number of tourists and residents on the basis of [4]

\begin{tabular}{|l|c|}
\hline \multicolumn{1}{|c|}{ Wskaźnik } & $\begin{array}{c}\text { Ilość obliczona } \\
\text { [jednostka] }\end{array}$ \\
\hline Założenia & \\
Ilość turystów: & $761500 \mathrm{os}$. \\
Ilość mieszkańców: & $2130000 \mathrm{os}$. \\
Ilość zebranych odpadów: & $411600 \mathrm{Mg} / \mathrm{rok}$ \\
Ilość dni spędzonych przez turystów w woj.: & śr. $4 \mathrm{dni}$ \\
Ilość dni spędzonych przez mieszkańców w woj. podkarpackim: & \\
\hline Obliczenia & $289 \mathrm{dni}$ \\
\hline Ilość turystów i mieszkańców: & 2891500 os. \\
Ilość odpadów zebranych w ciągu roku na mieszkańca: & $0,14 \mathrm{Mg} / \mathrm{os}$. rok \\
\hline Ilość odpadów przypadających na jednego turystę na rok: & $0,0368 \mathrm{Mg} / \mathrm{os}$. rok \\
Ilość odpadów przypadających na jednego mieszkańca na rok: & $0,1032 \mathrm{Mg} / \mathrm{os}$. rok \\
\hline $\begin{array}{l}\text { Ilość odpadów przypadających na jednego turystę na dzień: } \\
\text { Ilość odpadów przypadających na jednego mieszkańca na dzień: }\end{array}$ & $0,0092 \mathrm{Mg} / \mathrm{os}$. dzień \\
\hline
\end{tabular}

Odpady, które pozostawiają po sobie turyści, są dużym problemem, wpływającym na wszystkie elementy środowiska przyrodniczego. Gospodarka odpadami turystycznymi stanowi problem, ponieważ nie ma jednoznacznego sposobu określającego dokładną ilość odpadów, produkowanych przez turystów oraz osobnego sposobu kwalifikowania odpadów jako odpadu turystycznego - odpa- 
dy te zaliczane są do odpadów komunalnych. Deponowanie odpadów w środowisku przez turystów jest nieuniknione i wiąże się z naturalną koniecznością zaspokajania potrzeb życiowych związanych z wypoczynkiem. Natomiast ważny jest prawidłowy sposób ich zagospodarowania i niepozostawiania ich w środowisku przyrodniczym.

Problem gospodarki odpadami jest jasny, jednak nie jest doprecyzowany. Prawo powinno dokładnie określać zasady zagospodarowania odpadów, które wytwarzają turyści. Właściciele działek turystycznych powinni również ponosić odpowiedzialność zagospodarowania odpadami. Nowa ustawa „O utrzymaniu czystości i porządku w gminach" nie ustala zagospodarowania odpadów na terenach rekreacyjnych. Tereny te są dewastowane i zaśmiecane w okresach sezonowych a przez niedoprecyzowanie w ustawie definicji o nieruchomości zamieszkałej nie można wyegzekwować obowiązku utrzymania porządków i deklaracji o zbiórce odpadów od właścicieli tych działek. Poprawę zbiórki odpadów na ternach chronionych mogłyby zapewnić odpowiednie pojemniki umieszczane na szlakach lub miejscach uczęszczanych turystycznie oraz ich odpowiednie zabezpieczenie przed dewastacją nie tylko zwierząt ale i ludzi. Dzikie wysypiska śmieci, które oszpecają krajobraz oraz przyczyniają się do zanieczyszczeń wody i gleby nie miały by wtedy racji bytu $[1,3]$.

Na terenie Podkarpacia głównymi źródłami hałasu są wzmożony ruch samochodowy oraz praca ośrodków przemysłowych. Na Podkarpaciu te dwa czynniki nie powodują znaczącego wzrostu poziomu hałasu. W turystyce dominującym elementem, powodującym uciążliwość hałasem, jest natężenie ruchu samochodowego w sezonie letnim.

Ruch turystyczny nie wpływa na uciążliwość, spowodowaną hałasem komunikacyjnym, ponieważ w miejscowości o dużym natężeniu turystyki (Ustrzyki Dolne) jest porównywalny do miejscowości o średnim natężeniu ruchu turystycznego (Łańcut), natomiast największe przekroczenia poziomu hałasu występują w miejscowościach, w których dominuje przemysł (Nisko) [4].

Województwo podkarpackie charakteryzuje się stosunkowo małym zanieczyszczeniem powietrza (tab. 2) i koncentruje się na terenach przemysłowych oraz $\mathrm{w}$ takich powiatach jak mielecki, rzeszowski i stalowowolski. Emitorem zanieczyszczeń do powierza jest działalność elektrociepłowni, ciepłowni i komunalnych kotłowni. Niektóre z nich są bardzo uciążliwe dla środowiska, jednak coraz więcej z nich wyposażone jest w urządzenia odpylające najnowszej technologii. Zanieczyszczenia gazowe zmniejszyły się o 4,6\%, zmniejszyła się również ilość zanieczyszczeń powietrza gazowych zatrzymanych w urządzeniach do redukcji zanieczyszczeń o 9,3\%. Nastąpiło zwiększenie zatrzymania zanieczyszczeń pyłowych zatrzymanych $\mathrm{w}$ urządzeniach do redukcji zanieczyszczeń o 0,6\%. Powiaty, w których wytwarzana jest największa ilość zanieczyszczeń - to stalowowolski, niżański, tarnobrzeski, mielecki i dębicki. Na regionach tych nie ma lub są $\mathrm{w}$ niewielkim procencie położone obszary uczęszczane przez turystów. 
Tabela 2. Zestawienie wskaźników zanieczyszczeń powietrza zakładów przemysłowych wraz z skutecznością ich zatrzymania, na podstawie [3-4]

Table 2. List of indicators of air pollution industrial plants along with the effectiveness of their detention, based on [3-4]

\begin{tabular}{|c|c|c|}
\hline 2010 rok & 2012 rok & 2014 rok \\
\hline \multicolumn{3}{|c|}{$\begin{array}{l}\text { Wskaźnik: Emisja zanieczyszczeń gazowych z zakładów szczególnie uciążliwych ogółem } \\
\text { (tony/rok) }\end{array}$} \\
\hline 3402183 & 3701683 & 3244439 \\
\hline \multicolumn{3}{|c|}{$\begin{array}{l}\text { Wskaźnik: Emisja zanieczyszczeń pyłowych z zakładów szczególnie uciążliwych ogółem } \\
\text { (tony/rok) }\end{array}$} \\
\hline 1952 & 1954 & 1699 \\
\hline \multicolumn{3}{|c|}{$\begin{array}{l}\text { Wskaźnik: Zanieczyszczenia powietrza gazowe zatrzymane w urządzeniach do redukcji } \\
\text { zanieczyszczeń w \% wytworzonych }(\%) \text { z zakładów szczególnie uciążliwych ogółem (tony/rok) }\end{array}$} \\
\hline 35,6 & 38,2 & 26,3 \\
\hline \multicolumn{3}{|c|}{$\begin{array}{l}\text { Wskaźnik: Zanieczyszczenia powietrza pyłowe zatrzymane w urządzeniach do redukcji } \\
\text { zanieczyszczeń w \% wytworzonych }(\%) \text { z zakładów szczególnie uciążliwych ogółem (tony/rok) }\end{array}$} \\
\hline 98,7 & 99,5 & 99,3 \\
\hline
\end{tabular}

Działania naprawiające użytkowanie gleb na terenach uczęszczanych turystycznie powinny skupić się szczególnie na naprawie szlaków turystycznych oraz ich odpowiednie oznakowanie. Organy sprawujące nadzór nad obszarami chronionymi powinny skupić się na pośrednich czynnikach, mających wpływ na zanieczyszczenie gleb m.in. zaśmiecanie, nadmierna ilość spalin, wycinanie lasów.

Podkarpackie lasy są szczególnie uczęszczane przez turystów. Stopień zalesienia stanowi $36,8 \%$ powierzchni województwa. Biocenoza leśna jest siedliskiem dzikich zwierząt, bogatego runa leśnego oraz źródłem napędzającym gospodarkę lokalnych przedsiębiorstw. W województwie utworzono takie kompleksy leśne, jak „Leśne Kompleksy Promocyjne w Nadleśnictwie Bircza”, „Leśny Kompleks Promocyjny Lasy Bieszczadzkie” oraz część kompleksu „Lasy Janowskie w Nadleśnictwie Janów Lubelski” na terenie gmin Pysznica, Zaklików i Radomyśl. Lasy należące do Skarbu Państwa zajmują 85\% powierzchni województwa, natomiast pozostałe kompleksy leśne - to tereny prywatne, występują one na słabych jakościowo glebach. Podkarpacie względem lesistości podzielone jest na teren północny, środkowy i południowy. W części północnej występują lasy mieszane i sosnowe, środkowa część - to lasy mieszane, natomiast tereny południowe są najbardziej zróżnicowane pod względem gatunkowym drzew w lasach i jest to część województwa o największej lesistości oraz największej ingerencji turystów [5].

Zagrożeniami jakie stwarzają turyści są najczęściej pozostawiane odpady po biwakowaniu czy zakopywane dzikie wysypiska śmieci. Ścieżki leśne wy- 
znaczone są w najpiękniejszych częściach lasu i można tu spotkać rzadkie gatunki roślin i zwierząt. Są to najlepiej oznakowane szlaki przyrodnicze. Ważne jest zachowanie podstawowych zasad poruszania się po lasach, pamiętaniu o zachowaniu ciszy, niezaśmiecaniu, wyprowadzaniu psów na smyczy (ponieważ niszczą one runo leśne, lub mogą atakować dzikie zwierzęta) oraz biwakowaniu w wyznaczonych miejscach [5].

Woda zanieczyszczana jest głownie przez awarie sprzętu wodnego, wycieki paliw z silników żaglówek lub lodzi, środki czyszczące używane przez turystów wypoczywających nad jeziorem. Problemem jest również nieszczelna sieć kanalizacyjna, przez którą przedostają się ścieki. Zanieczyszczenia te są przyczyną eutrofizacji zbiorników, skażenia substancjami chemicznymi oraz powodują ubożenie różnorodności ryb znajdujących się w wodach. Na Podkarpaciu wybudowanych jest 13 elektrowni wodnych. Zidentyfikowano kilka miejsc złóż źródeł geotermalnych dotychczas nie eksploatowanych m.in. w miejscowościach Kuźmina, Brzegi Dolne, Polańczyk [1].

Poprzez „Krajowy Program Oczyszczalni Ścieków Komunalnych” i jej szerszy dostęp dla mieszkańców (również dla turystów) wzrasta ilość ścieków komunalnych. Na obszarach chronionych wykonuje się ocenę wymagań dodatkowych określonych dla jednolitych części wód powierzchniowych. W 2014 roku badania te potwierdziły, że 2 z 4 obszarów chronionych, na których była badana woda, nie spełniało wymagań do celów rekreacyjnych („Potok Chotowski” i „Brusienka”), w tym kąpieliskowych. 43 z 94 badanych obszarów zakwalifikowano jako wrażliwe na eutrofizację, która spowodowana jest zanieczyszczeniami pochodzenia komunalnego. Poprawę jakości wód widać również w ocenie spełnienia wymagań dodatkowych dla obszarów chronionych wód powierzchniowych przeznaczonych do poboru wody przeznaczonej do spożycia z 2012 roku na stanowiskach Wisłoka - od potoku Chotowskiego do Rzeki, Wisłoka - od potoku Kiełkowskiego do ujścia, Sanu - od Huczek do Wisłoka bez Wisłoki, Sanu - od Olszanki do Wiaru (badania wody pod względem: jakości, stanu fizykochemicznego i stanu bakteriologicznego) nie spełniły wymagań dla obszaru chronionego $[4,6]$.

Cennym obszarem przyrodniczym jest zbiornik Solina a jego ochrona przed zanieczyszczeniami jest szczególnie ważna. Zlewnia zbiornika znajduje się na obszarach chronionych (park narodowy, rezerwaty przyrody, parki krajobrazowe) oraz zaopatruje w wodę pobliskie miejscowości. Na jego terenie prowadzone jest jedynie działalność turystyczno-rekreacyjna. W 2014 roku w zlewni Zbiornika Solina wykonano kontrolę zakładów odprowadzania ścieków do wód powierzchniowych i stwierdzono 91,5\% naruszeń dotyczących ochrony środowiska w kontrolowanych zakładach. Największy problem stanowi nielegalne odprowadzanie ścieków do zbiornika Solina przez gospodarstwa agroturystyczne. Ludność utrzymuje się w dużym stopniu z działalności agroturystycznej jednak aby poprawić jakość wód należy zwiększyć świadomość ekologiczną mieszkańców, aby zadbali o właściwe odprowadzanie ścieków z swoich gospo- 
darstwach nie zatruwając tym samym własnej okolicy. Poprawę stanu jakości tych wód umożliwiałby zakładanie przydomowych biologiczno-mechanicznych oczyszczalni ścieków, oraz pomoc finansowa ze strony samorządu na szerzenie takich działań.

\section{Podsumowanie}

Na obszarze województwa podkarpackiego występuje wiele walorów turystycznych, przez co staje się ono bardzo atrakcyjne. Walory te są walorami przyrodniczymi, antropogenicznymi, wypoczynkowymi, zdrowotnymi, oraz typowo krajoznawczymi. Poprzez dobre warunki turystyczne w tym regionie następuje wzrost zainteresowania nim ze strony turystów, a to z kolei przyczynia się do zwiększenia ofert turystycznych, ilości ośrodków wypoczynkowych i turystycznych baz zatrzymania.

Województwo podkarpackie jest rejonem, w którym ludność utrzymuje się głównie z rozwoju turystyki. Szerzenie wiedzy na temat najlepszych technik, które można zastosować w gospodarstwach przyjmujących turystów lub miejscach zakwaterowania i ich wykorzystanie poprawiłaby stan środowiska przez zmniejszenie zanieczyszczeń.

Po przeprowadzonej analizie stwierdzono, ze turystyka pośrednio wpływa na zanieczyszczenia gleby, powierza oraz ma nieznaczny udział w poziomie hałasu komunikacyjnego. Nie oznacza to jednak, że jej wpływ jest niegroźny i nieistotny Aby o tym się przekonać należy wykonać specjalne badania, które określiłyby stopień, w jakim turystyka może przyczynia się do tego typu zanieczyszczeń.

Turystyka podkarpacka w dalszym stopniu będzie się rozwijać, natomiast razem z nią będą rozwijały się kierunki, formy i techniki, które wykorzystywane będą do ochrony środowiska przyrodniczego. Wraz z szerzeniem ochrony środowiska na Podkarpaciu turyści dłużej będą mogli cieszyć się wspaniałymi walorami przyrodniczymi, które tu występują, ponieważ nadmierne eksploatowanie i braki w zabezpieczeniu przyrody będą powodowały ubożenie i utratę rangi walorów i tym samym brak zainteresowania turystów tym regionem.

\section{Literatura}

[1] Strategia rozwoju województwa Podkarpackiego na lata 2007-2020. Aktualizacja 2010. Rzeszów: sierpień 2010 r. Zarząd Województwa Podkarpackiego.

[2] Cisek B. Żegleń P.: Analiza rozwoju turystyki w woj. podkarpackim w kontekście rozwoju turystyki w Polsce i na świecie. ASM Centrum Badan i Analiz Rynku Sp. z o.o.

[3] Raport o stanie środowiska w województwie podkarpackim w 2014 roku. Rozdział 8. Odpady, Biblioteka Monitoringu Środowiska, Rzeszów: Biblioteka Monitoringu Środowiska, 2014 r. 
[4] Raport o stanie środowiska w województwie podkarpackim w 2013 roku, Opracowano w Wydziale Monitoringu Środowiska Wojewódzkiego Inspektoratu Ochrony Środowiska w Rzeszowie, Rzeszów: Biblioteka Monitoringu Środowiska, 2013 r.

[5] Strategia rozwoju turystyki na obszarach chronionych (dotyczy górskich obszarów województwa podkarpackiego). Sanok: 2014 r. Fundacja Karpacka - Polska.

[6] Rak J.: Wskazania, odczyty i rozliczenia za zużytą wodę. II Konferencja Błekitny San nt. „Ochrona środowiska, walory przyrodnicze i rozwój turystyki w Dolinie Sanu”, Związek Gmin Turystycznych Pogórza Dynowskiego, Dynów, 2005, s. 31-40.

\section{ENVIRONMENTAL PROTECTION IN TOURISM IN PODKARPACIE}

\section{S u m m a r y}

The article presented an analysis of regional environmental podkarpacki tourist contaminated waste. Podkarpackie province is popular with places of tourist activity and good tourist infrastructure networks. Research shows that Podkarpacie is a province with a slight pollution. Surface waters are the main source of demand for Podkarpacie. Through its geographical location province can be considered one of the few places in Poland where the tourist season lasts almost all year round. Podkarpacie through it attracts tourists who want an active rest for communing with nature. The sudden development of tourism was caused by promoting the region as an attractive tourist destination in the region and welcomed tourists. One of the major problems hampering the development of tourism is too small network of tourist information. They are arranged in a few strategic places for tourists. They can be found even a few kilometers from bus stops or train stations. For tourists who come to a new place, it is important to obtain any information about the city, accommodation or monuments that are located in the area. Analysis has shown that tourists generate on average up to thirty times more waste than the average citizen Podkarpackie province, which is caused by the use of larger quantities of disposable packaging, production waste such as food scraps, textiles, glass, etc. After this analysis, it was found that indirectly affect tourism pollution of soil, air, and has a negligible share in the level of traffic noise. This does not mean, however, that its effect is harmless and irrelevant. To realize this should make special research that would determine the extent to which tourism can contribute to this type of pollution.

Keywords: Podkarpacie, tourism, pollution, environment, network site

Przestano do redakcji: $10.02 .2016 r$.

Przyjęto do druku: 1.03.2016 r.

DOI: $10.7862 /$ rb.2016.110 